\title{
RANCANG BANGUN APLIKASI SMS GATEWAY PADA SMK TRISAKTI DI BANDAR LAMPUNG
}

\author{
Pitrawati $^{1}$, Marta Graccelia Pasaribu ${ }^{2}$ \\ Komputerisasi Akuntansi ${ }^{1}$, Manajemen Informatika ${ }^{2}$ \\ AMIK Dian Cipta Cendikia, Bandar Lampung \\ Jl. Cut Nyak Dien No. 65 Durian Payung (Palapa) Bandar Lampung \\ E-mail : pitrawati@dcc.ac.id, liamartha15@gmail.com
}

\begin{abstract}
ABSTRAK
Teknologi yang berkembang saat ini semakin pesat terutama untuk kepentingan organisasi usaha. Perkembangannya bahkan sudah mencapai dunia pendidikan. Salah satu teknologi yang sedang berkembang saat ini adalah SMS Gateway, SMS Gateway sangat dibutuhkan karena SMS Gateway dapat menyajikan berbagai informasi yang berkaitan dengan perkembangan siswa.

Tahapan pengembangan aplikasi SMS gateway menggunakan metode Extreme Programming dimana alat perancangan yang digunakan adalah usecase, activity diagram dan class diagram. Software pengembangan yang digunakan adalah lunak PHP (Hypertext Preprocessor), Xampp dan MySQL

Hasil dari penelitian ini adalah terciptanya sebuah sistem penerapan informasi berbasis SMS Gateway untuk memberikan kemudahan siswa-siswi dan orangtua murid untuk mengetahui informasi sekolah dengan lebih cepat dan lengkap, memberikan informasi sekolah lebih efektif dan efisen serta meningkatkan layanan informasi kepada orang tua murid
\end{abstract}

Kata kunci : Teknologi, Informasi, SMS Gateway, Extreme Programming

\section{PENDAHULUAN}

Perkembangan teknologi telekomunikasi selular berawal dari keinginan orang untuk dapat berkomunikasi tanpa harus terpaku pada suatu tempat saja melainkan dapat bergerak bebas sesuai dengan keinginan orang tersebut. Salah satu dari bagian itu adalah berupa pesan singkat yang biasa disebut SMS (Short Messaging Service). SMS merupakan salah satu fitur GSM yang dikembangkan dan distandarisasi oleh ETSI yaitu badan standar telekomunikasi Eropa yang menstandarisasikan SMS dan fitur-fitur GSM lainnya.

Penggunaan SMS pada saat ini sangat banyak digunakan oleh pengguna telepon seluler, hal ini dikarenakan biaya yang sangat murah dan kegagalan penerimanya sangat kecil. Sekolah Menengah Kejuruan (SMK) Trisakti Bandar Lampung merupakan instansi sekolah menegah kejuruan swasta yang memiliki lebih dari 300 murid dan wali murid yang semuanya membutuhkan informasi terbaru tentang sekolah. Penyampaian informasi yang ada di SMK Trisakti yang masih menggunakan media kertas dan papan pengumuman, membuat masyarakat dan siswa kesulitan dalam mandapatkan informasi tentang sekolah, kegiatan sekolah, dan materi pelajaran. Masyarakat atau kalangan siswa yang membutuhkan informasi sekolah harus datang dan melihat di papan pengumuman atau bertanyalangsung ke petugas atau guru sekolah, sehingga penyampaian informasi membutuhkan waktu yang lama. Sistem penyampaian informasi yang demikian menjadi kendala bagi sekolah untuk bisa lebih dikenal dan diketahui oleh masyarakat luas.

Teknologi SMS Gateway sebagai media penyampaian informasi akan lebih cepat, SMS gateway merupakan salah satu metode penyampain informasi yang dapat mendukung kerja website dalam penyampaian informasi ke orangtua siswa, meski tidak membuka website 
sekolah informasi akan dikirim berupa pesan singkat yang akan diterima orangtua siswa melalui handphone, sehingga memudahkan bagi orangtua murid ataupun siswa-siswi untuk mengetahui berbagai infromasi atau kegiatan sekolah yang mecakup sekolah mereka serta memberikan akses kepada orangtua agar mengetahui kegiatan anak-anaknya dalam bersekolah.

Oleh karena itu, perlunya sebuah aplikasi penerapan informasi memudahkan siswa-siswi serta orangtua murid dalam mengetahui infomasi sekolah, kegiatan sekolah.

\subsection{Identifikasi Masalah}

Berdasarkan latar belakang diatas dapat diidentifikasi masalah sebagai berikut :

1. Kesulitan dalam mandapatkan informasi tentang sekolah dan kegiatan sekolah bagi siswa-siswi serta orangtua murid.

2. Lambatnya penyampaian informasi membuat kendala bagi sekolah untuk bisa lebih dikenal dan diketahui oleh masyarakat luas.

\subsection{Rumusan Masalah}

Berdasarkan permasalahan diatas dapat dirumusakan masalah sebagai berikut :

1. Bagaimana merancang dan membangun aplikasi yang dapat menyampaikan informasi sekolah, kegiatan sekolah dan materi pelajaran yang ada di SMK Trisakti.

2. Bagaimana menerapkan metode SMS Gateway untuk memberikan informasi ke orangtua siswa?

\subsection{Batasan Masalah}

Adapun batasan masalah dalam penyusunana penelitian ini diantaranya :

1. Dalam pembuatan sistem informasi ini membutuhkan data yang ada di SMK Trisakti diantaranya : data siswa, data berita.

2. Sistem informasi ini akan melakukan beberapa proses diantaranya proses penyimpanan data siswa, berita, dan pengiriman melalui sms gateway.

3. Output yang akan di hasilkan sistem informasi ini yaitu text berita, dan pesan singkat yang dikirimkan ke No.handphone orangtua siswa sekolah.

\subsection{Tujuan Penelitian}

Adapun tujuan dalam penyusunana penelitian ini
1. Merancang dan membuat aplikasi penerapan informasi sekolah berbasis SMS gateway yang memberikan informasi sekolah lebih efektif dan efisen.

2. Meningkatkan layanan informasi kepada orang tua murid.

\subsection{Tujuan Penelitian}

Adapun tujuan dalam penelitian ini :

1. Merancang dan membuat aplikasi penerapan informasi sekolah berbasis SMS gateway yang memberikan informasi sekolah lebih efektif dan efisen.

2. Meningkatkan layanan informasi kepada orang tua murid.

\subsection{Manfaat Penelitian}

Manfaat penelitian ini adalah

1. Memberikan kemudahan siswa-siswi dan orangtua murid dalam mengetahui mengenai informasi sekolah dengan lebih cepat dan lengkap.

2. Memudahkan pihak sekolah dalam mengumumkan atau menyampaikan informasi kepasa siswa maupun orang tua murid.

\section{METODE PENELITIAN}

\subsection{Metode Penelitian}

Jenis penelitian yang digunakan adalah deskriptif. Penelitian deskriptif adalah survei, metode survei merupakan penyelidikan yang diadakan untuk memperoleh fakta-fakta dari gejala-gejala yang ada dan mencari keteranganketerangan secara faktual baik tentang institusi sosial, ekonomi, atau politik dari suatu kelompok maupun suatu daerah (Nazir, 2014).

Metode pengembangan perangka lunak dengan menggunakan Extreme Programming (XP). Extreme Programming (XP) merupakan suatu pendekatan yang paling banyak digunakan untuk pengembangan perangkat lunak cepat.

Landasan penggunakan metode Extreme Programming (XP) karena sifat dari aplikasi yang dikembangkan dengan cepat melalui tahapan- tahapan yang ada meliputi : planning design, coding dan testing.

\subsection{Teknik Pengumpulan Data}

Dalam penelitian ini teknik pengumpulan data menggunakan beberapa metode antara lain adalah :

1. Metode Wawancara

2. Metode Observasi 


\section{Metode Kepustakaan}

\subsection{Alat Pengembangan Sistem}

Menurut Nugroho (2010) mengemukakan :

UML (Unified Modeling Language) adalah sebuah bahasa untuk menentukan, visualisasi, kontruksi, dan mendokumentasikan artifact (bagian dari informasi yang digunakan atau dihasilkan dalam suatu proses pembuatan perangkat lunak. Artifact dapat berupa model, deskripsi atau perangkat lunak) dari sistem perangkat lunak, seperti pada pemodelan bisnis dan sistem non perangkat lunak lainnya.

UML merupakan bahasa standar untuk penulisan blueprint software yang digunakan untuk visualisasi, spesifikasi, pembentukan dan pendokumentasian alatalat dari sistem perangkat lunak.

\subsubsection{Use Case Diagram}

Menurut Rosa dan Shalahuddin, (2014) mengemukakan :

Use Case Diargam merupakan pemodelan untuk melakukan (behavior) sistem informai yang akan dibuat. Use case digunakan untuk mengetahui fungsi apa saja yang ada di dalam sebuah sistem informasi dan siapa saja yang berhak menggunakan fungsi-fungsi itu. Berikut adalah simbol-simbol yang ada pada diagram use case.

Tabel 1. Simbol Use Case

\begin{tabular}{|c|c|c|c|}
\hline No & Notasi & Keterangan & Simbol \\
\hline 1 & Actor & $\begin{array}{l}\text { Pengguna sistem } \\
\text { atau yang } \\
\text { berinteraksi } \\
\text { langsung dengan } \\
\text { sistem }\end{array}$ & \\
\hline 2 & $\begin{array}{l}\text { Use } \\
\text { Case }\end{array}$ & $\begin{array}{l}\text { Lingkaran elips } \\
\text { dengan nama use } \\
\text { case nya tertulis } \\
\text { ditengah lingkaran }\end{array}$ & Use Case \\
\hline \multirow[b]{2}{*}{3} & \multirow{2}{*}{$\begin{array}{l}\text { Assocat } \\
\text { ion }\end{array}$} & \multirow{2}{*}{$\begin{array}{l}\text { Garis yang } \\
\text { berfungsi } \\
\text { menghubungkan } \\
\text { actor dengan use } \\
\text { case. }\end{array}$} & \\
\hline & & & \\
\hline 4 & Relasi & $\begin{array}{l}\text { Sebagai } \\
\text { penghubung } \\
\text { antara actor } \\
\text { usecase, use case- }\end{array}$ & -- \\
\hline
\end{tabular}

\begin{tabular}{|c|c|c|c|}
\hline & & usecase dll & \\
\hline 5 & $\begin{array}{l}\text { Include } \\
\text { Relatio } \\
\text { nship }\end{array}$ & $\begin{array}{l}\text { Memungkinkan } \\
\text { suatu usecase } \\
\text { untuk } \\
\text { menggunakan } \\
\text { fungsionalitas } \\
\text { yang disediakan } \\
\text { oleh usecase yang } \\
\text { lainnya. }\end{array}$ & $\begin{array}{l}<<\text { include } \gg> \\
--\rightarrow\end{array}$ \\
\hline 6 & $\begin{array}{l}\text { Extend } \\
\text { Relatio } \\
\text { nship }\end{array}$ & $\begin{array}{l}\text { Memungkinkan } \\
\text { usecase memiliki } \\
\text { kemungkinan } \\
\text { untuk memperluas } \\
\text { fungsionalitas } \\
\text { yang disediakan } \\
\text { oleh usecase yang } \\
\text { lainnya. }\end{array}$ & 《extend $\gg>$ \\
\hline
\end{tabular}

\subsubsection{Activity Diagram}

Menurut Rosa dan Shalahuddin, (2014) mengemukakan :

Activity Diagram menggambarkan workflow (aliran kerja) atau aktivitas dari sebuah sistem atau proses bisnis atau menu yang ada pada perangkat lunak. Perlu diperhatikan bahwa diagram aktivitas menggambarkan aktivitas sistem bukan apa yang dilakukan aktor, jadi aktivitas yang dapat dilakukan oleh sistem. Berikut adalah simbol-simbol yang ada pada diagram aktivitas.

Tabel 2. Simbol Activity Diagram

\begin{tabular}{|l|l|l|l|}
\hline No. & Notasi & Keterangan & Simbol \\
\hline 1 & $\begin{array}{l}\text { Initial } \\
\text { State }\end{array}$ & $\begin{array}{l}\text { Titik awal } \\
\text { untuk memulai } \\
\text { suatu aktivitas }\end{array}$ & \\
\hline 2 & $\begin{array}{l}\text { Final } \\
\text { State } \\
\text { untuk } \\
\text { mengakhiri } \\
\text { suatu aktivitas } \\
\text { Menandakan } \\
\text { sebuah aktivitas }\end{array}$ & \\
\hline 4 & $\begin{array}{l}\text { Activity } \\
\text { Mon }\end{array}$ & $\begin{array}{l}\text { Pilihan untuk } \\
\text { pengambilan } \\
\text { keputusan }\end{array}$ & \\
\hline
\end{tabular}




\begin{tabular}{|l|c|l|l|}
\hline 5 & $\begin{array}{c}\text { Control } \\
\text { Flow }\end{array}$ & Arus aktivitas & $\longrightarrow$ \\
\hline 6 & ForkJoin & $\begin{array}{l}\text { Menunjukkan } \\
\text { kegiatan } \\
\text { menggabungka } \\
\text { n dua panel } \\
\text { activity menjadi } \\
\text { satu atau satu } \\
\text { panel activity } \\
\text { menjadi dua }\end{array}$ & \\
\hline 8 & Note & $\begin{array}{l}\text { Tanda } \\
\text { penerimaan }\end{array}$ & \\
\hline 9 & $\begin{array}{l}\text { Lno receive action> } \\
\text { Catatan khusus } \\
\text { untuk sebuah } \\
\text { aktivitas }\end{array}$ & \\
\hline & & \\
\hline
\end{tabular}

\subsubsection{Class Diagram}

Menurut Rosa dan Shalahuddin (2013) mengemukakan :

Class Diagram menggambarkan struktur sistem dari segi pendefinisian kelaskelas yang akan dibuat untuk membangun sistem. Kelas memiliki apa yang disebut atribut dan metode atau operasi. Berikut adalah simbol-simbol yang ada pada diagram Kelas.

Tabel 3. Simbol Class Diagram

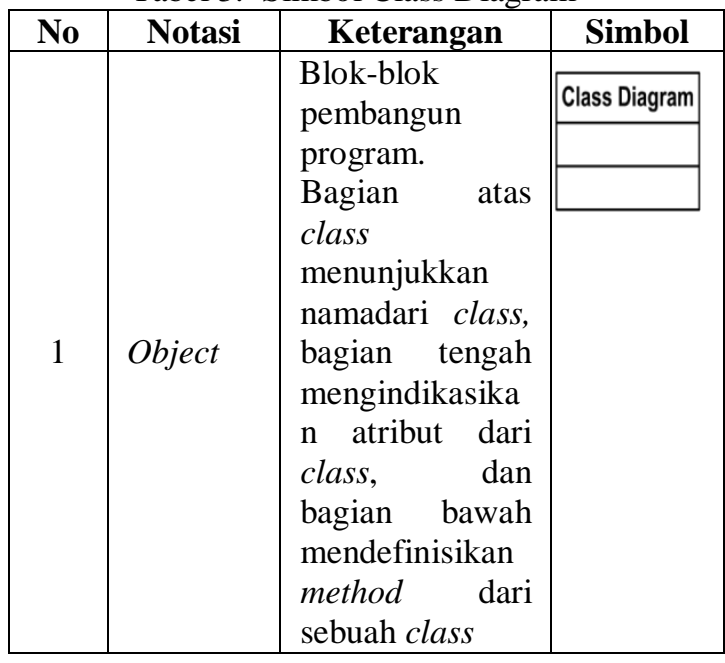

\begin{tabular}{|c|c|l|l|}
\hline 2 & $\begin{array}{c}\text { Activatio } \\
n\end{array}$ & $\begin{array}{l}\text { Menunjukkan } \\
\text { relationship atau } \\
\text { hubungan antar } \\
\text { class }\end{array}$ & \\
\hline 3 & Lifeline & $\begin{array}{l}\text { Menunjukkan } \\
\text { ketergantungan } \\
\text { antara satu class } \\
\text { dengan class } \\
\text { yang lain }\end{array}$ & \\
\hline
\end{tabular}

\subsection{Bahasa Pemrograman}

\subsubsection{SMS Gateway}

Menurut Daud Edison Tarigan dalam halaman http://eprints.dinus.ac.id/11898/1/jurnal_11604.p df/ 2012 mengemukakan

SMS Gateway merupakan pintu gerbang bagi penyebaran informasi dengan menggunakan SMS. Anda dapat menyebarkan pesan kebanyak nomor secara otomatis dan cepat yang langsung terhubung dangan database nomor-nomor ponsel saja, tanpa harus mengetik ratusan nomor dan pesan dari ponsel karena semua nomor akan diambil secara otomatis dari database tersebut.

\section{Class Diagra}

\subsubsection{Xampp}

Xampp adalah perangkat lunak opensource yang bisa diunggah secara gratis dan bias dijalankan di semua sistem operasi seperti Windows, Linux, Solaris dan Mac. Xampp ini sendiri dibuat dan dikembangkan oleh Apache Friends Perangkat lunak tersebut berisi beberapa kumpulan perangkat lunak yang dibutuhkan, antara lain PHP, Apache, MySQL, dan PHPMyAdmin. Dengan melakukan instalasi Xampp, maka semua perangkat lunak yang dibutuhkan sudah terinstal di hardisk, termasuk file-file yang dibutuhkan.

\subsubsection{MySQL}

Menurut Arief (2011) mengemukakan :

"MySQL adalah salah satu jenis database server yang sangat terkenal dan banyak digunakan untuk membangun aplikasi web yang menggunakan database sebagai sumber dan pengolahan datanya".

Menurut Priyanto dan Jauhari

(2014) mengemukakan :

MySQL merupakan salah satu mesin yang menangani pengolahan basis data. MySQL adalah salah satu DBMS yang 
sering digunakan untuk pengolahan data-data pada program aplikasi web seperti yang dibuat dengan menggunakan PHP. Dengan MySQL, aplikasi tidak hanya bisa diakses database pada satu komputer saja tetapi dapat digunakan untuk diakses pada banyak komputer. Hal ini sering disebut dengan penanganan komunikasi data antar komputer (client server).

\section{HASIL DAN PEMBAHASAN}

\subsection{Hasil Penelitian}

\subsubsection{Analisa Kebutuhan Sistem}

Analisa kebutuhan sistem pada penelitian ini dilakukan dengan mengumpulkan data - data melalui observasi, wawancara, studi kepustakaan dan dokumentasi yang dilakukan pada SMK Trisakti Bandar Lampung. Berdasarkan hasil pengumpulan data maka penulis dapat mengindentifikasikan masalah yang terjadi dimana kesulitan dalam mandapatkan informasi tentang sekolah dan kegiatan sekolah bagi siswasiswi serta orangtua murid serta lambatnya penyampaian informasi membuat kendala bagi sekolah untuk bisa lebih dikenal dan diketahui oleh masyarakat luas, maka dengan dibangunnya penerapan informasi kepada siswa siswi serta orangtua dapat memberikan kemudahan siswasiswi dan orangtua murid dalam mengetahui mengenai informasi sekolah dengan lebih cepat dan lengkap dan memudahkan pihak sekolah dalam mengumumkan atau menyampaikan informasi kepasa siswa maupun orang tua murid.

Dari Sistem informasi untuk penerapan informasi sekolah bagi Siswa-Siswi Berbasis SMS Gateway pada SMK Trisakti Bandar Lampung yang akan dibuat didefinisikan bentuk kebutuhan fungsional sebagai berikut :

Aplikasi dapat mengirimkan sms mengenai :

a. Pengumuman

Pengumuman akan dikirim kepada orang tua atau wali siswa baik lewat broadcast/request.

b. Sistem membantu orangtua mengetahui perkembangan anaknya disekolah.

c. Sistem memberikan informasi secara efektif kepada siswa dan orangtua siswa tanpa harus datang ke sekolah langsung.

\subsubsection{Analisa Kebutuhan Input dan Output 3.1.2.1 Kebutuhan Input}

Kebutuhan input yang digunakan untuk mengoperasikan penerapan Informasi kepada siswa-siswi dan orangtua murid

1. User

2. Input Data Siswa

3. Input Data Orangtua atau Wali

\subsubsection{Kebutuhan Output}

Kebutuhan output yang digunakan untuk sebuah penerapan informasi kepada siswa-siswi dan orangtua murid pada SMK Trisakti Bandar Lampung ini adalah Output Laporan Data Pesan Terkirim

\subsection{Perancangan Sistem \\ 3.2.1 Use Case Diagram}

Use case diagram yaitu salah satu jenis diagram pada UML yang menggambarkan interaksi antara sistem dan aktor, use case diagram juga dapat men-deskripsikan tipe interaksi antara si pemakai sistem dengan sistemnya.

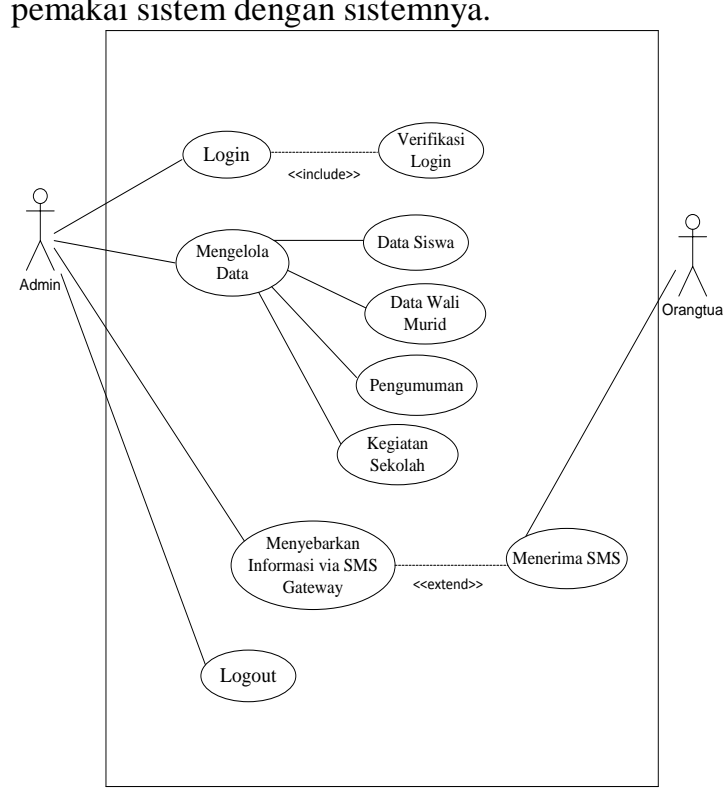

Gambar 1. Use Case Diagram

\subsubsection{Class Diagram}




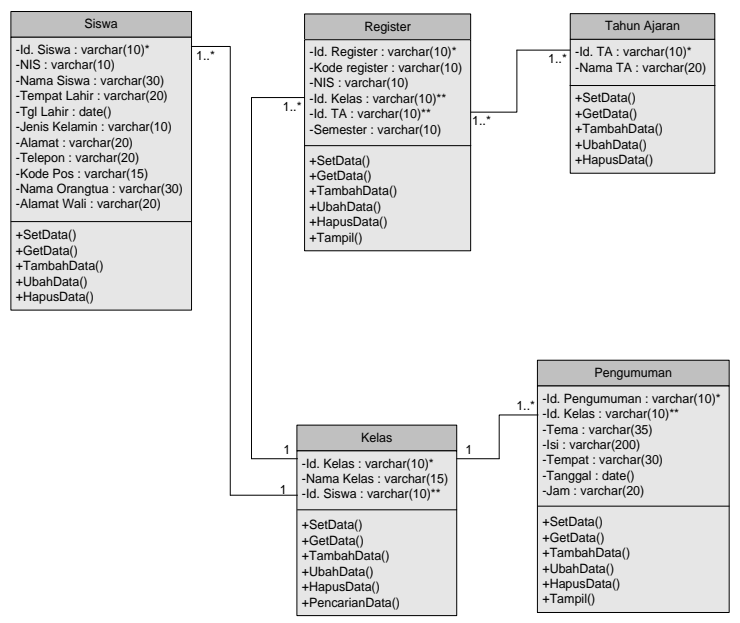

Gambar 2. Class Diagram

\subsubsection{Activity Diagram}

Activity Diagram ini menggambarkan rangkaian aliran dari aktivitas, digunakan untuk mendeskripsikan aktivitas yang dibentuk dalam suatu operasi sehingga dapat juga digunakan untuk aktivitas lainnya seperti use case atau interaksi. Activity diagram dapat dilihat pada gambar di bawah ini:

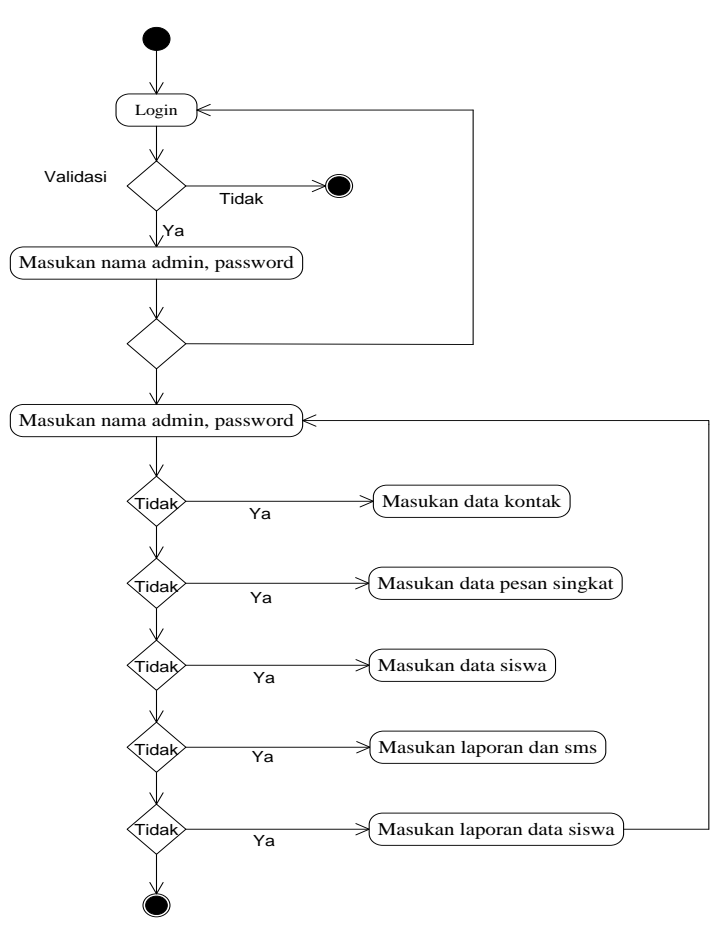

Gambar 3. Activity Diagram Menu Utama

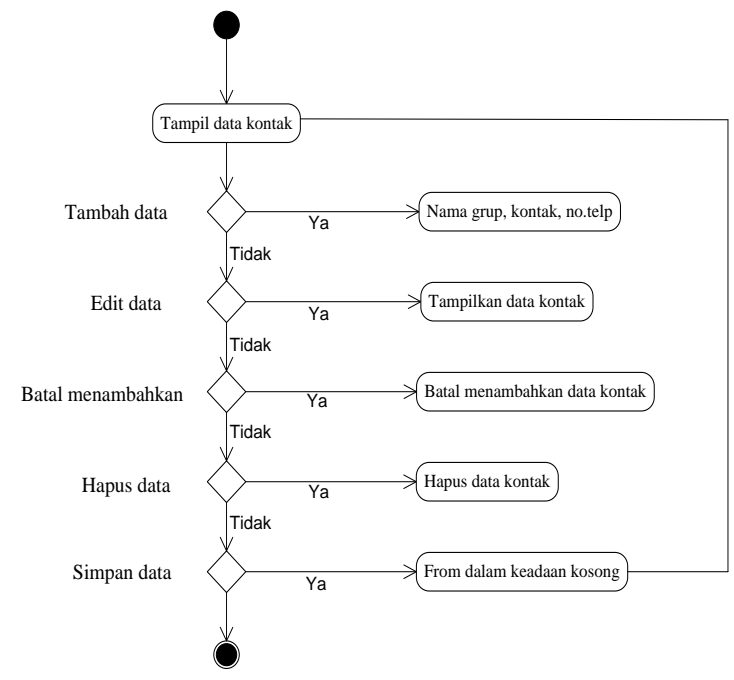

Gambar 4. Activity Diagram Data Kontak

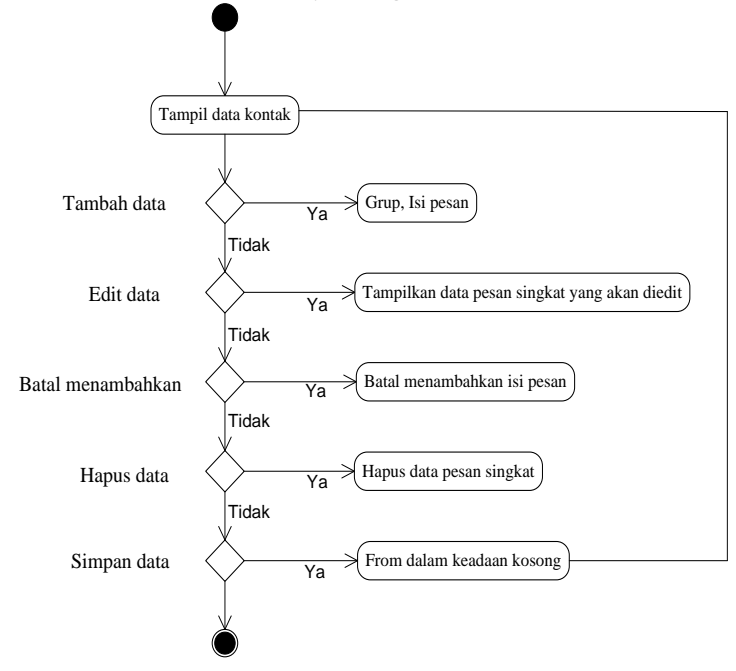

Gambar 5. Activity Diagram Pesan Singkat

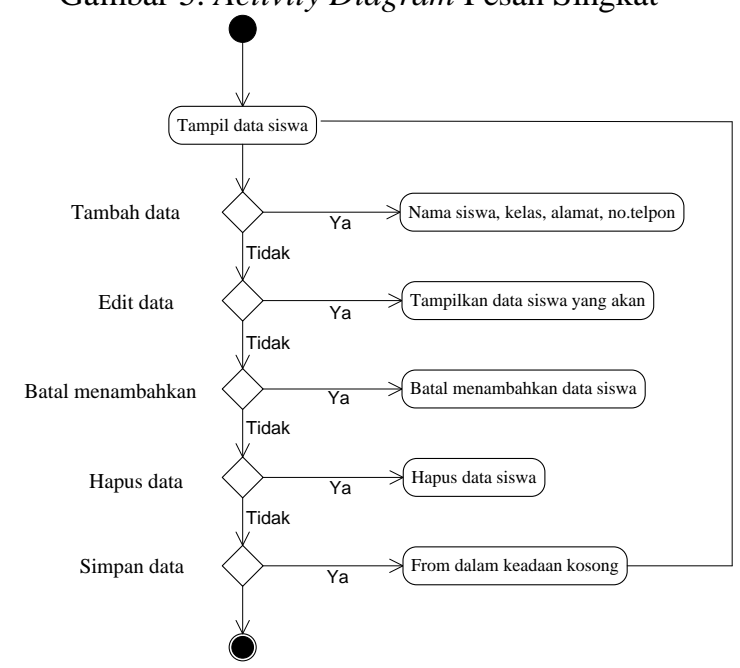


Gambar 6. Activity Diagram Data Siswa

\subsubsection{Rancangan Tampilan Form Login}

Tampilan halaman login adalah tampilan halaman yang berfungsi untuk memeberikan hak akses untuk msuk ke dalam sistem. Tampilan halaman login dapat dilihat pada gambar 7

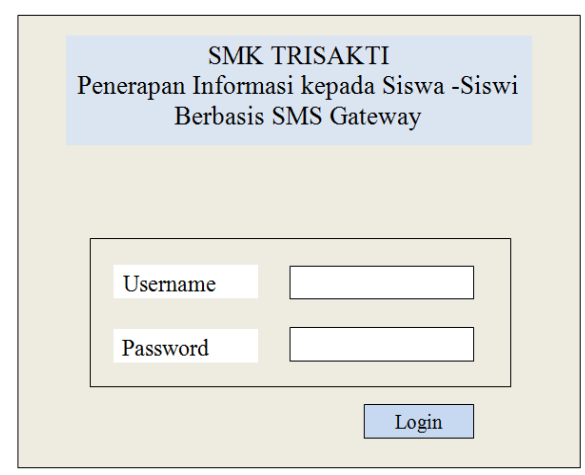

Gambar 7. Rancangan Tampilan Form Login

\subsubsection{Rancangan Tampilan Menu Utama}

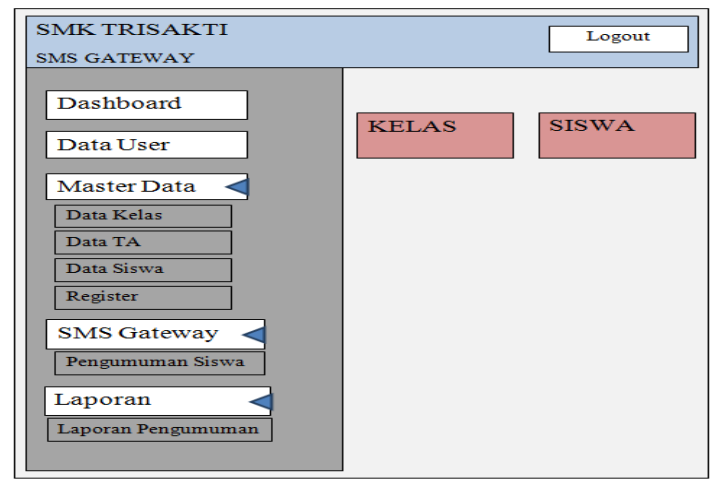

Gambar 8. Rancangan Tampilan Menu Utama

\subsubsection{Rancangan Tampilan Data User}

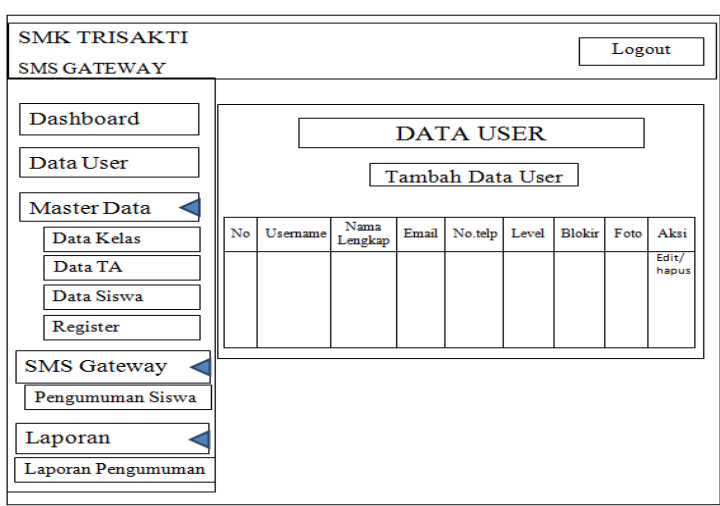

Gambar 9. Rancangan Tampilan Data User

\subsubsection{Rancangan Tampilan Data Kelas}

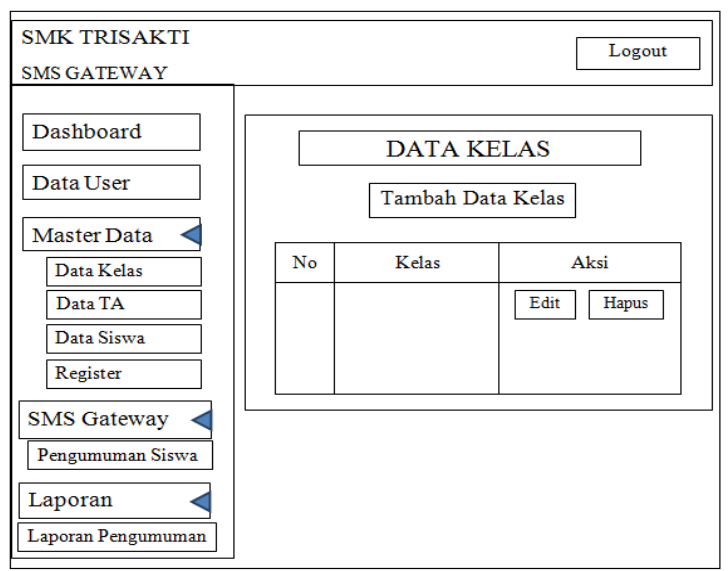

Gambar 10. Rancangan Tampilan Data Kelas

\subsubsection{Rancangan Tampilan Data Tahun Ajaran}

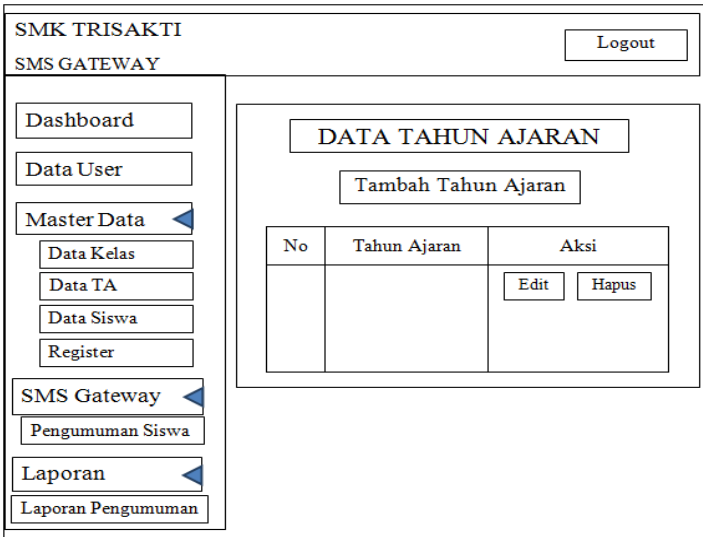

Gambar 11. Rancangan Tampilan Data Tahun Ajaran

\subsubsection{Rancangan Tampilan Data Siswa}

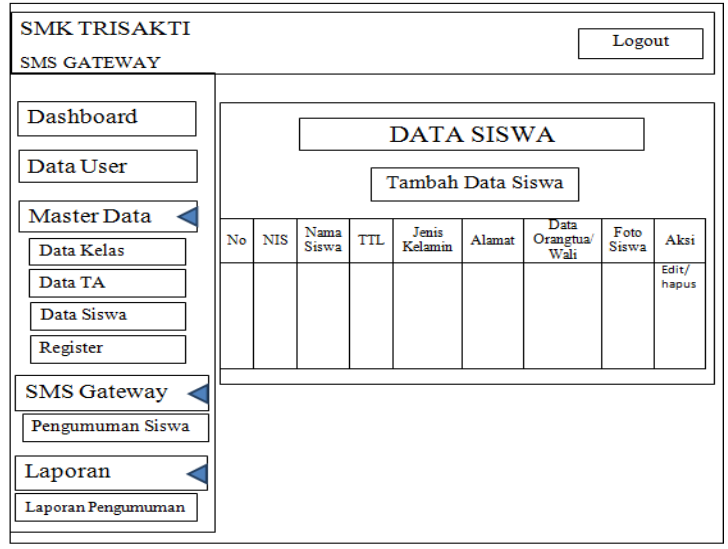


Gambar 12. Rancangan Tampilan Data Siswa

\subsubsection{Rancangan Tampilan Data Registrasi}

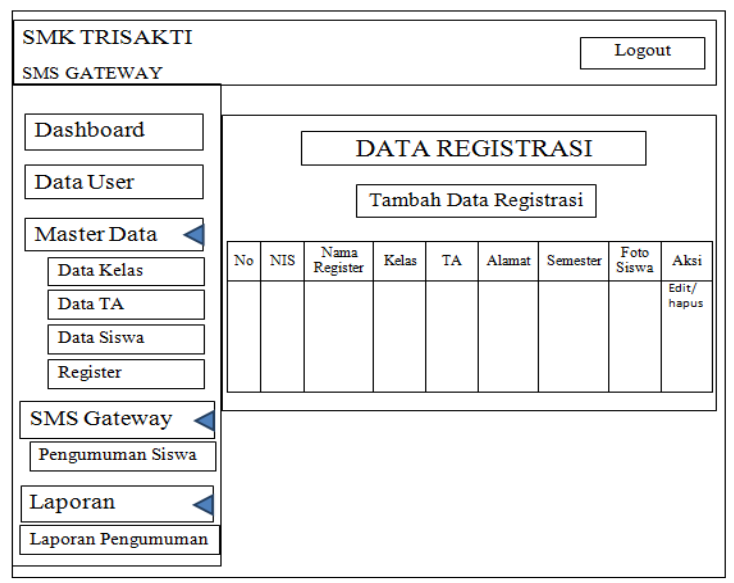

Gambar 13. Rancangan Tampilan Data Registrasi

\subsubsection{Rancangan Tampilan Data Pengumuman}

\begin{tabular}{|l|l|l|l|l|l|l|l|l|}
\hline SMK TRISAKTI \\
SMS GATEWAY
\end{tabular}

Gambar 14. Rancangan Tampilan Data Pengumuman

\subsection{PEMBAHASAN}

\subsection{Hasil Penelitian}

Sistem yang dibuat berhasil menghasilkan informasi mengenai penerapan informasi sekolah kepada siswa-siswi dan orangtua murid berbasis SMS Gateway. Sistem yang dibuat dapat digunakan oleh admin dalam memberitahukan pengumuman sekolah. Tahap ini akan menjelaskan bagaimana sistem ini bekerja sebagai alat bantu dalam memberitahukan pengumuman kepada siswa-siswi dan orangtua murid. Berikut merupakan penjelasan dari setiap komponen sistem penerapan informasi sekolah di SMK Trisakti Bandar Lampung.

\subsubsection{Perangkat Lunak Yang Digunakan}

Perangkat lunak yang berfungsi untuk melakukan pengerjaan dalam data processing system untuk mendukung bekerjanya sistem komputer. Adapun kebutuhan yang dibutuhkan adalah seperti dibawah ini:

\section{BOOTSTRAP}

Bootstrap adalah toolkit yang dibuat oleh Twitter. Jadi kita sedikit terbantu untuk membuat web application ataupun website.

2. XAMPP

Software paketan yang dipakai MySQL yang berfungsi sebagai database server.

\subsection{Pembahasan}

Hasil program dan pembahasan adalah pembahasan yang bertujuan untuk memberikan pembahasan mengenai hasil program yang telah dibuat.

\subsubsection{Tampilan Halaman Menu Utama}

Tampilan halaman menu utama adalah tampilan yang akan muncul ketika admin mengakses sistem penerapan informasi sekolah. Tampilan halaman menu utama dapat dilihat pada gambar 15

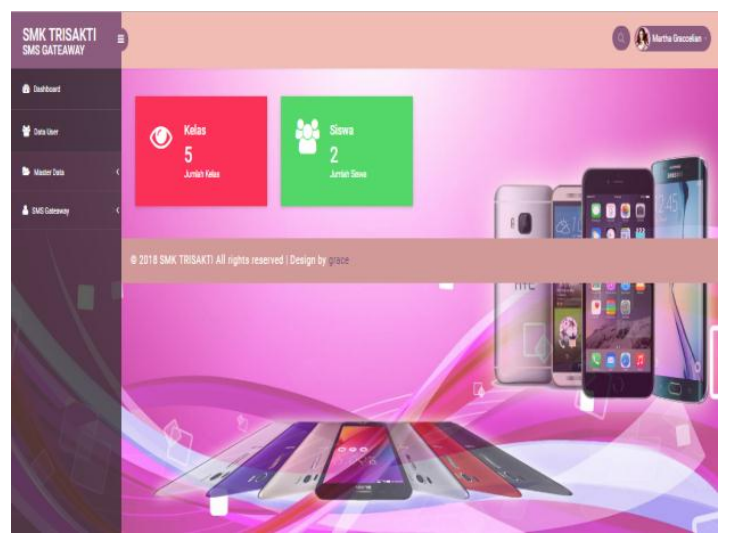

Gambar 15. Tampilan Halaman Menu Utama

\subsubsection{Tampilan Halaman Login}

Tampilan halaman login adalah tampilan halaman yang berfungsi untuk memeberikan hak akses untuk msuk ke dalam sistem. Tampilan halaman login dapat dilihat pada gambar 16 


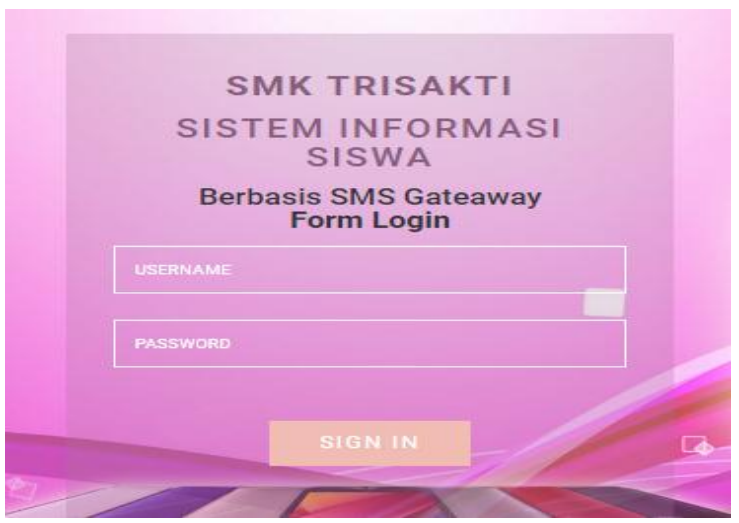

Gambar 16. Tampilan Halaman Login

\subsubsection{Tampilan Halaman Data User}

Tampilan halaman data admin adalah tampilan yang berfungsi untuk mengelola data admin, baik melihat, menambahkan, mengubah dan menghapus data admin. Data admin dimaksudkan adalah data petugas dan admin itu sendiri. Data yang berhasil dimasukkan akan mendapatkan hak akses ke dalam sistem. Rancangan tampilan halaman data user dapat dilihat pada gambar 17

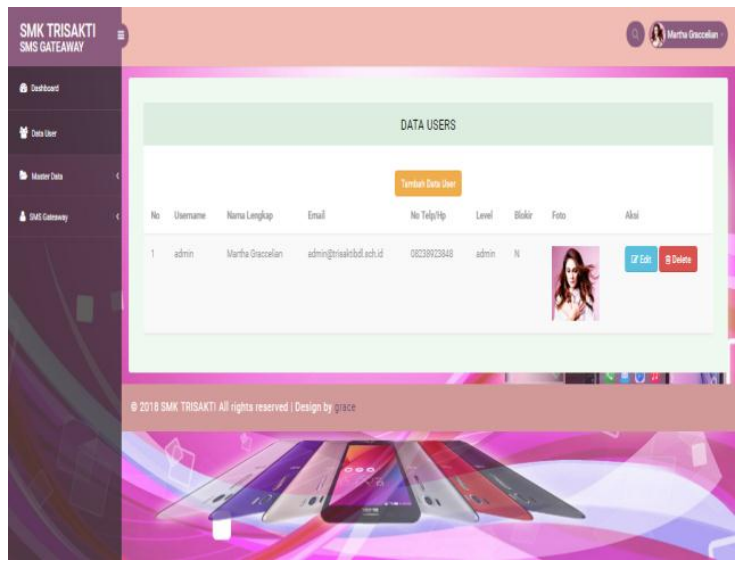

Gambar 17. Tampilan Halaman Data User

\subsubsection{Tampilan Halaman Ubah Data User}

Tampilan halaman ubah data user adalah tampilan halaman yang berfungsi untuk mengubah data admin. Tampilan ubah data admin dapat diakses dengan menekan tambah data user yaitu ubah pada tabel data user. Tabel data user berada pada halaman data user yang berisikan semua informasi dari data user. Halaman ubah data user dapat dilihat pada gambar 18

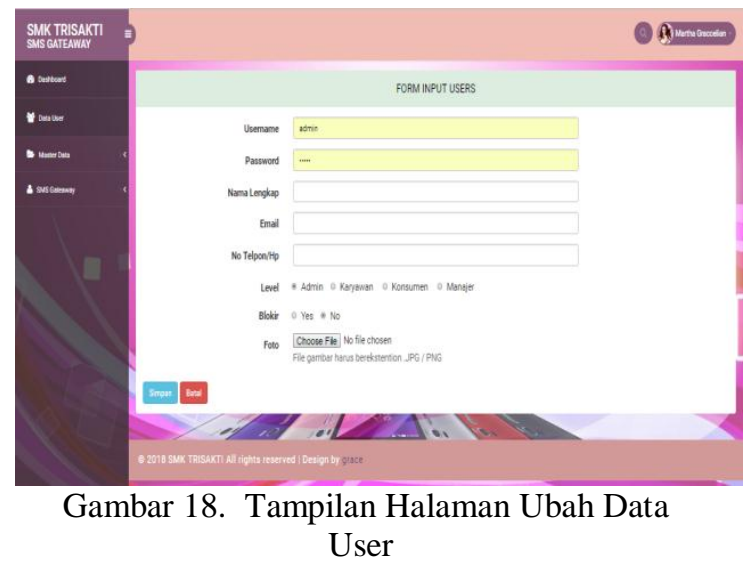

\subsubsection{Tampilan Halaman Data Kelas}

Tampilan halaman data kelas adalah tampilan yang berfungsi untuk mengelola data kelas. Data kelas merupakan data utama dalam sistem penerapan informasi sekolah. Tampilan halaman data kelas akan menyajikan semua kelas yang memudahkan dalam mencari kelas. Tampilan halaman data kelas juga dapat menghapus data kelas bila terjadi kesalahan dalam memasukkan data. Tampilan halaman data kelas dapat dilihat pada gambar 19

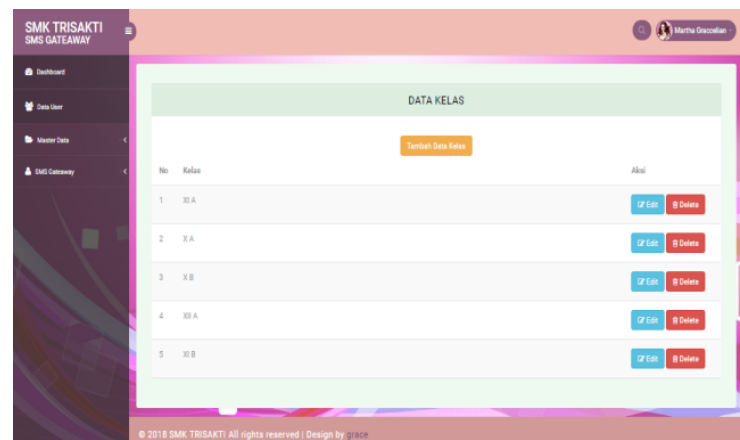

Gambar 19. Tampilan Halaman Data Kelas

\subsubsection{Tampilan Halaman Ubah Data Kelas} Tampilan halaman ubah data kelas adalah tampilan halaman yang berfungsi mengubah data kelas yang berhasil dimasukkan sebelumnya. Tampilan halaman ubah data kelas dapat dilihat pada gambar 20

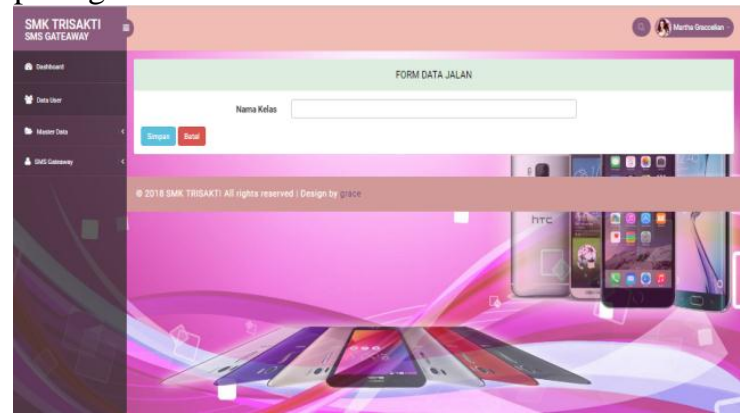


Gambar 20. Tampilan Halaman Ubah Data Kelas

\subsubsection{Tampilan Halaman Data Tahun Ajaran}

Tampilan halaman data tahun ajaran adalah tampilan halaman yang berfungsi untuk mengelola data tahun ajaran dimana data siswasiswi bisa terdata sesuai tahun ajarannya. Rancangan tampilan halaman data tahun ajaran dapat dilihat pada gambar 21

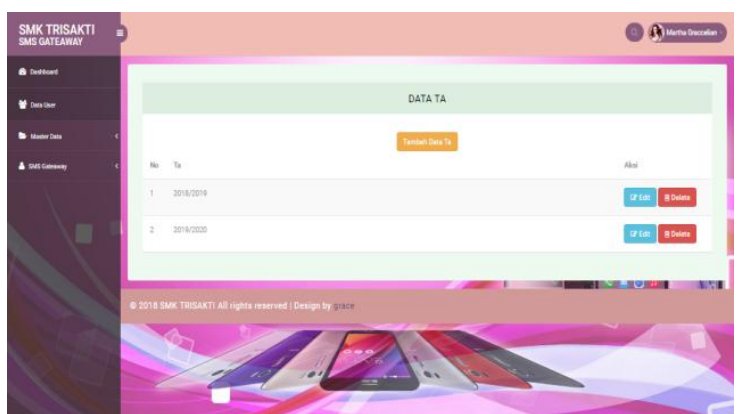

Gambar 21. Tampilan Halaman Data Tahun Ajaran

\subsubsection{Tampilan Halaman Tambah Data Tahun Ajaran}

Tampilan halaman tambah data tahun ajaran adalah tampilan halaman yang berfungsi untuk menambah data tahun ajaran baru, tanpa mengubah tahun ajaran yang sudah ada. Tampilan halaman tambah data tahun ajaran dapat dilihat 22

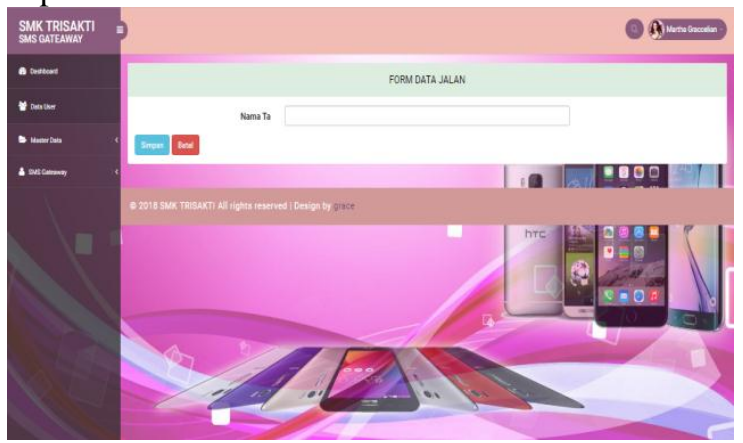

Gambar 22. Tampilan Halaman Tambah Data Tahun Ajaran

\subsubsection{Tampilan Halaman Data Siswa}

Tampilan halaman data siswa adalah tampilan halaman yang berfungsi untuk mengelola data siswa. Data siswa digunakan untuk mendata siswa yang masih bersekolah serta bisa mengetahui data orangtua murid dan tidak terjadi kesalahan dalam pengolahan data. Tampilan halaman data siswa dapat dilihat pada gambar 23

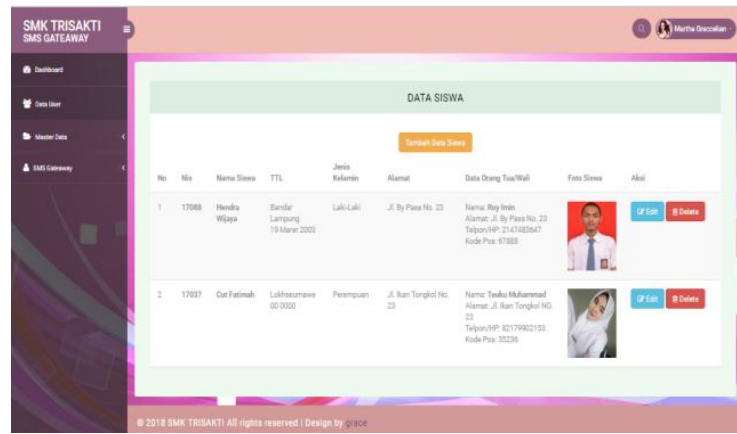

Gambar 23. Tampilan Halaman Data Siswa

\subsubsection{Tampilan Halaman Tambah Data Siswa}

Tampilan halaman tambah data siswa adalah tampilan yang berfungsi untuk menambah data siswa jika ada siswa baru yang masuk atau siswa yang belum terdata sebelumnya. Tampilan halaman tambah data siswa dapat dilihat pada gambar 24

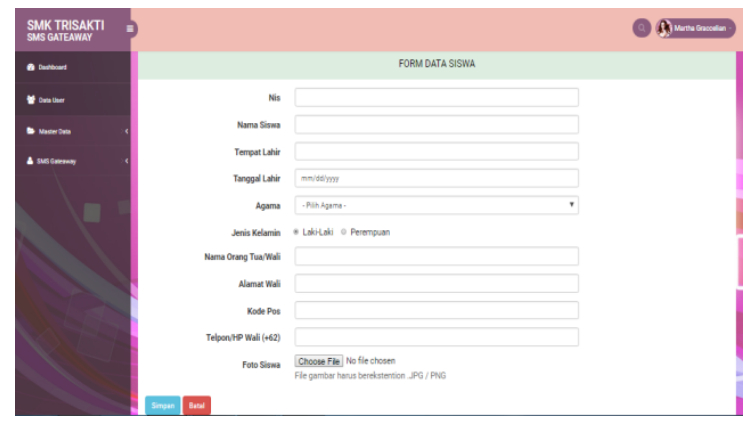

Gambar 24. Tampilan Halaman Tambah Data Siswa

\subsubsection{Tampilan Halaman Data Registrasi} Tampilan halaman data registrasi tampilan halaman yang berfungsi untuk mendata ulang kembali siswa-siswa tahun ajaran baru. Tampilan halaman data registrasi dapat dilihat pada gambar 25

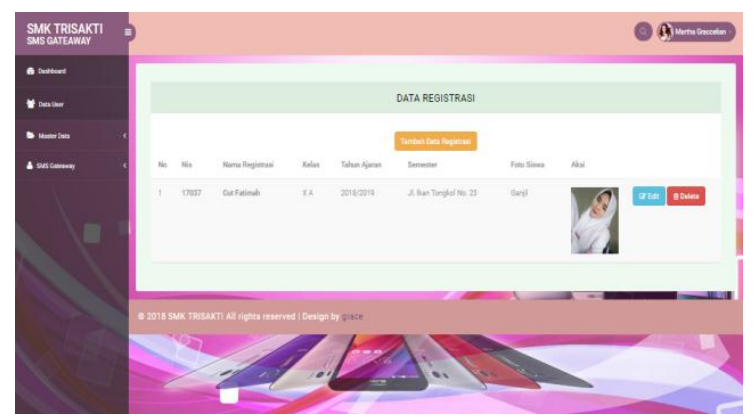

Gambar 25. Tampilan Halaman Data Registrasi 


\subsubsection{Tampilan Halaman Tambah Data Registrasi}

Tampilan halaman tambah data registrasi adalah tampilan halaman yang berfungsi untuk menambah data siswa dalam tahun ajaran baru. Tampilan halaman tambah data registrasi dapat dilihat pada gambar 26

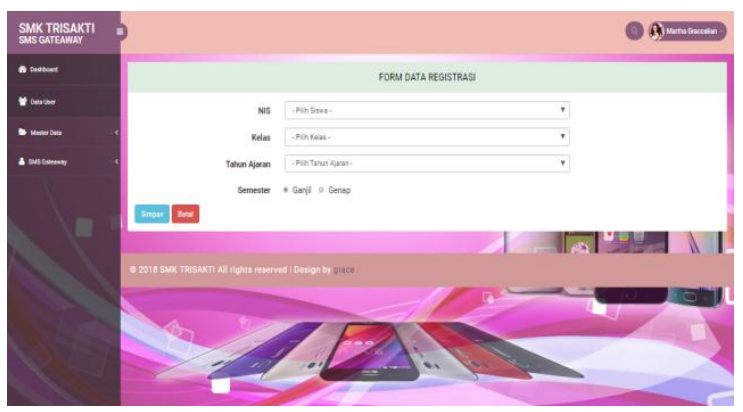

Gambar 26. Tampilan Halaman Tambah Data Registrasi

\subsubsection{Tampilan Halaman Data Pengumuman}

Tampilan Halaman data pengumuman adalah tampilan yang berfungsi untuk mendata data pengumuman yang sudah terkirim. Data pengumuman juga bisa di edit jika terjadi kesalahan Tampilan halaman data pengumuman dapat dilihat pada gambar 27

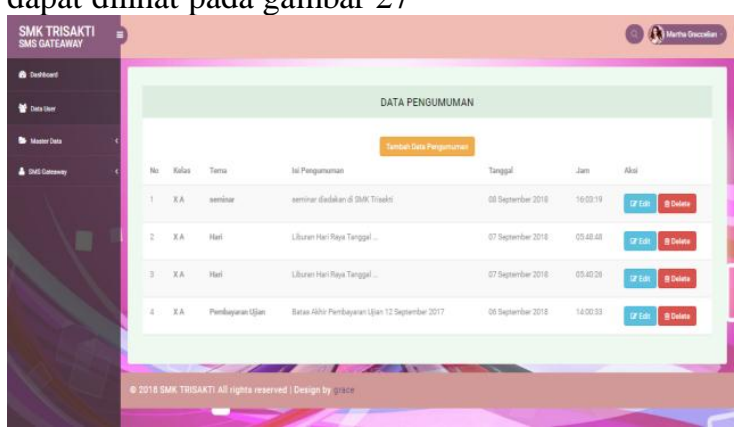

Gambar 27 Tampilan Halaman Data Pengumuman

\subsubsection{Tampilan Halaman Tambah Data Pengumuman}

Tampilan halaman tambah data pengumuman adalah Tampilan halaman dimana untuk menambah informasi kegiatan sekolah dan untuk menuliskan pengumuman serta tema yang akan dikirimkan kepada orangtua murid. Tampilan halaman tambah data pengumuman dapat dilihat pada gambar 28

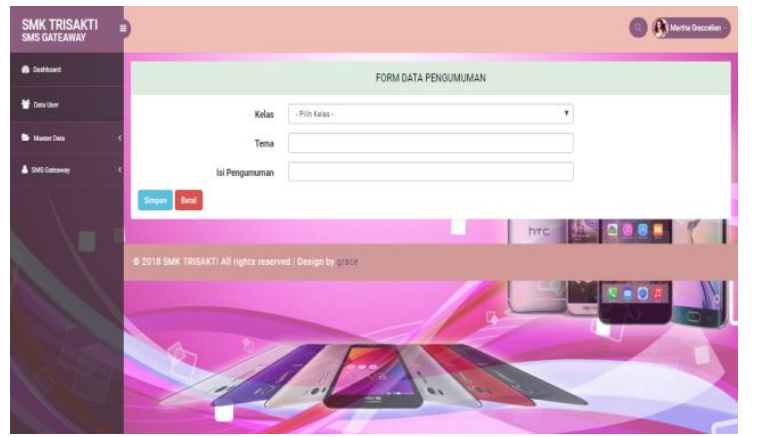

Gambar 28. Tampilan Halaman Tambah Data Pengumuman

\section{PENUTUP}

Berdasarkan rumusan masalah, hasil penelitian dan pembahasan mengenai sistem penerapan informasi sekolah berbasis SMS Gateway dapat diambil beberapa kesimpulan yaitu:

1. Penerapan Informasi Sekolah berbasis SMS Gateway menyajikan sebuah penerapan informasi serta kegiatan sekolah atau pengumuman sekolah melalui sms yang dapat langsung disampaikan kepada orangtua murid seccara lebih efektif dan efisien.

2. Penerapan Informasi Sekolah berbasis SMS Gateway meningkatkan layanan informasi kepada orang tua murid yang berguna memberikan kemudahan siswa-siswi dan orangtua murid dalam mengetahui mengenai informasi sekolah dengan lebih cepat dan lengkap, serta memudahkan pihak sekolah dalam mengumumkan atau menyampaikan informasi kepada siswa maupun orang tua murid.

3. Penerapan Informasi Sekolah berbasis SMS Gateway dapat dikembangkan kembali dengan lebih baik sehingga memberikan informasi nyang benar dan lengkap kepada orangtua murid.

4. Penerapan Informasi Sekolah berbasis SMS Gateway dapat dikembangkan dengan pemanfaatan teknologi sehingga lebih memudahkan orangtua murid dalam mengetahui kegiatan anak-anaknya di sekolah.

\section{DAFTAR PUSTAKA}

[1] Arief, M.Rudianto, 2011, Pemrograman Web Dinamis Menggunakan Php dan Mysql, ANDI : Yogyakarta.

[2] A. S., Rosa dan Shalahuddin, M. 2013, Rekayasa Perangkat Lunak 
Terstruktur Dan Berorientasi Objek. Informatika. Bandung.

[3] Adi Nugroho, 2010, Rekayasa Perangkat Lunak Berbasis Objek dengan Metode USDP. Andi. Yogyakarta

[4] Edison, Daud Tarigan, 2012, Membangun SMS Gateway, Buku Membangun SMS Gateway Yogyakarta. Universitas Indonesia http://eprints.dinus.ac.id/11898/1/jur nal_11604.pdf

[5] Moh. Nazir, 2014. Metodologi Penelitian, Ghalia Indonesia, Bogor

[6] Priyanto, Jauhari, 2014, Pemrograman Web, Bandung: Informatika Bandung

[7] Rossa, \& Shalahuddi, 2011, Rekayasa Perangkat Lunak Terstruktur dan Berorientasi Objek, Informatika Bandung, Bandung.

[8] Rosa dan Shalahuddin, 2014, Rekayasa Perangkat Lunak Struktur dan Berorientasi Objek. Bandung : Informatika. 